\title{
Sarmatyja (2018)
}

Author: Maryja Martysievich

Minsk: Janushkievich Publishing

Language: Belarusian

Maryja Martysievich excels as a poet, and translates literature into Belarusian from Czech, English, Polish, Russian and Ukrainian. The title of her story, Sarmatyja, told in thirty cantos, refers to the Grand Duchy of Lithuania, which present-day Belarusians claim as their own. From the 16th to the 18th centuries, the Grand Duchy of Lithuania and the Kingdom of Poland constituted the Commonwealth of Poland-Lithuania. This composite and electoral monarchy's nobility saw themselves as descendants of these proud Iranic warriors, or Sarmatians, in contrast to the 'lowly and unkempt' Slavic serfs, who were compelled to toil for free on their noble lords' fields until the $1860 \mathrm{~s}$.

The volume's protagonist, Heloise, is a free-spirited woman of independent means who follows her dream to visit Sarmatia. She travels from Italy to the grand duchy and records her impressions in this poetic memoir. First and foremost, she is on a quest for love. Religion is not important, but it is the politics of power and economy that governs who marries whom. However, as a foreigner of a presumably noble status, Heloise shuns conventions and loves whom and when she wants. Snow, the cold, boundless woods and ubiquitous mud make travel a slow and hard-going experience, which requires long sojourns en route, enabling Heloise to woe Sarmatian men. In letters to her sister, she describes the wide realm, its beautiful capital of Vilnia, but also the pogroms of Jews. Heloise realizes that the Sarmatians as a people belong to antiquity. She likens the grand duchy's nobles - who claim this disappeared people as their ancestors - to 'Martians,' or bellicose sons of Mars. They have no choice but hone their military skills, because 'zombies,' or Muscovites, constantly threaten their lands. This playfulness with words indicates that the story is as much about the duchy as about today's Belarus. In Canto One, for instance, Heloise is overjoyed that no visa is required to travel to Sarmatia. It is an anachronistic allusion to the European Union's visa waver granted to Ukraine in 2017, a system of which many Belarusians dream.

Heloise's sister wants to join her in this Sarmatia of handsome noblemen, but Heloise advises against such a long and arduous travel. Along the way, perhaps it was discovered that she was not a noblewoman, or stepped on a jealous Sarmatian woman's toes, or was accused of witchcraft on account of her beauty, independence and promiscuity, but Heloise was punished by burning at the stake. Heloise says that she would burn as 'this Hannah' who met her fiery death 'tied to a pine'. This is a direct reference to a folksong of a serf girl who was burned to 
death because she did not allow her noble lord to have his way with her. This song also serves as the leitmotif of Alhierd Bacharevich's 2015 feminist novel White Fly, Men Killer, and perhaps inspired Martysievich's poetic story about Heloise's unrequited love. In the last sentence of the final chapter, Heloise pledges to her Sarmatian lover who failed to save her, that the smell of her burnt flesh will haunt him whenever he prepares a meat dish. Through the mouth of her brave protagonist, Martysievich accuses contemporary Belarusian and European society of oppressive patriarchalism that keeps women down and allows them to be killed with impunity. The poet is a worthy inheritor of the first self-conscious and renowned Belarusian writer Alaiza Pashkievich, popularly known as 'Auntie' in Belarusian literature.

TOMASZ KAMUSELLA

University of St. Andrews 